\title{
LETTERS OF BISHOP FISHER,
}

\section{52 I - 3.}

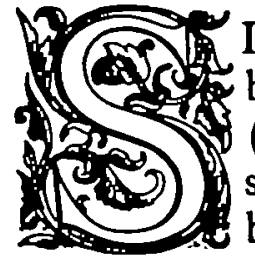

INCE my communication concerning bishop Fisher's sermons against Luther (3rd Series, III. 55) I have met with some interesting letters written on behalf of the Bishop by his chaplain, Richard Sharpe, to Dr. Nicholas Metcalfe, Master of St. John's College, Cambridge, and Archdeacon of Middlesex, which, from internal evidence, can be dated circa $152 \mathrm{I}-3$.

These letters are printed with some notes by Mr. R. F. Scott (now Master of St. John's College) in 'The Eagle' of March, 1893 (vol. xvii, 470-8), and $I$ have extracted the five here reprinted by the courtesy of Mr. R. F. Scott, because they contain references to the first of these sermons against Luther, incidentally to John Siberch's printing at Cambridge, early references to John Gough, Wynkyn de Worde, John Reynes, and others, of interest to bibliographers as containing new and important information.

The writer, Richard Sharpe, finds no place in the 'Dictionary of National Biography' nor in Cooper's 'A thenae Cantabrigienses.' He proceeded B.A., $1502-3$, M.A., I 507-8, B.D., I $516-7$, D.D., 1522-3 (Grace Book r. p. 425). In 6 Hen. 8 


\section{LETTERS OF BISHOP FISHER.}

(22nd April, 1514-2ist April, 1515) he was appointed the first President of St. John's College (Mayor's Baker's St. Johns I. 28r), and he was chaplain to bishop Fisher.

Dr. Nicholas Metcalfe, to whom these letters were addressed, was the son of Richard Metcalfe, of Beare Park, in Aysgarth, Richmondshire. He graduated B.A. I 494, B.D. I 504, D.D. 1507 . He was chaplain to bishop Fisher, and by him appointed Master of St. John's College, Cambridge, in 1518 , resigned $4^{\text {th }}$ July, 1537 , and died 1539 at Woodham Ferrers, Essex, of which place he had been appointed rector 3oth July, I 517. About 1515 he was instituted Archdeacon of Rochester (Cooper's 'Ath. Cant.' I. 62, and 'University Grace Books' B \& $\Gamma$ ).

Addressed: To the ryght worshipfull Maist Docto $^{\text {r }}$ Metcalfe, Archdiacon of Rochest.

After all due and humble recomendacions hade to your maistershipe with like thanks for your charitable luffe \& fauor alway towards me, like it yor maistershipp to vndrestande that my lorde ys in gude helth lovyde be our lord and desireth your maistershipe that by your gude means he may have wrytyn iiij sermons of seynt John Chrisostome concra iudeos with certain homelis de incomprehensibilitate dei \& other moo as they folow in the same boke. The boke lyeth in the new lybrary (of the Universite) (that byshop Rotheram made) and was delyuered at the last beyng of my lorde ther. For he had borowd $y^{t}$ of the Uniursite before. I have sende to my gude \& speciall maist the maist of Christes College the statutes for the new felows, your maist'shipe $\&$ he may rede them our at yor lesur \& see how yow like the. I have wrytyn to hym 


\section{LETTERS OF BISHOP FISHER. 135}

also for to helpe that the foresaid workes of seynt John Chrisostome may be wrytyn and sende to my lorde for it was my lord his mynd that I should wryt to you both for the same thynge as knows our lorde who preserve your maistershipe at Rochest the $x x$ day of october by yo bedma.

\section{Richarde Sharpe.}

This letter was, no doubt, sent to Dr. Metcalfe at Cambridge. Mr. Scott prints it immediately after two from his mother and aunt (1522) of a private character. The borrowing by bishop Fisher of the MS. of St. Chrysostom from the University Library is a much earlier instance than that of Cheke, who, in 154I, borrowed the MS. of Tzetzes' 'Scholia on Hesiod' (Henry Bradshaw's 'Papers,' p. 190, The University Library).

The Master of Christ's College was John Watson, D.D., the friend and correspondent of Erasmus, appointed Master I 517 , died I 530.

The other letters were evidently sent to Dr. Metcalfe in London, where he resided 'at Master Hudsons be syde Polles swarff' (or at 'Hudsons bruer at Polles swarff,' compare Stow's 'Pauls Wharf, a noted stairs for watermen, and on each side of the stairs is a very handsome house, one made use of by a Brewer, and the other for a timber yard,' Stow's 'Survey of London ').'

We know that he was constantly travelling about on the business of his college. This is shown by the three volumes of his private accounts, 1523-4-5, which the college possesses (Scott, 467).

$$
\text { I Scott, pp. 476, 479, } 473 \text {. }
$$




\section{${ }_{136}$ LETTERS OF BISHOP FISHER.}

(2)

Addressed: To the right worshipfull $\mathrm{M}^{\mathrm{r}}$ Doctor Metcalf archdiacon of Rochester.

My dewty of recomendacions presuposyd like yor maistershipe to know I haue recyvyd the matters $y^{t}$ ye sende to Grvyshende and I send yow a copye of oon of the indenturs the last weke of John Botells wrytyng \& bycause it is not delyured to yor maistershipe $I$ haue sende now on of the said indenturs sealyd with $\mathrm{M}^{\mathrm{r}}$ Ashton's seall \& subscribed with his own hande. My lord desyreth yo maistershipe to sende his bokes fro John Gogh and sende his sermon as shortly as can be that $\mathbf{M}^{\mathbf{r}}$ secretary hath. My lorde is very sory that the last part of his sermon is lost it will cost hym sa labor for I thynke he haue not the copye also my lords desyreth yow to send annotationes Erasmi left with Arnold to mende the byndyng of them My lord takith great labors agayns Luther 1 thynke verely that ys worke shall passe all other mens Our lorde sende hym stryngth $\&$ helth and I dowt not but he shall doo that thynge that shall be both profitable to the faith of Criste \& also for his honor \& fame as knows almyghty gode who preserve yor maistershipe.

yor bedman

Richard Sharpe.

Mr. Ashton was Hugh Ashton, M.A. (Oxford), I 507, LL.B. (Cambridge), I 507-8 ('Grace Book' 1. 65). He was comptroller of the household of the Lady Margaret, countess of Richmond and Derby, and, along with bishop Fisher, one of the executors of her will. He was Archdeacon of York from 1516 , died 23rd November (or Derember?), 1522 , and was buried in York Cathedral (Cooper's 'Athenae Cantab.' and 'D.N.B.').

John Botell (or Bottell), the writer, is again mentioned in letter (4). 
John Gough appears in the next letter to which my notes are attached. The sermon which ' $\mathrm{Mr}$. Secretary hath' was, no doubt, the one preached by bishop Fisher at St. Paul's, I 2th May, 1521, mentioned in the third letter, which, upon this occasion, Mr. Secretary Pace had for the purpose of making the Latin version, afterwards printed at Cambridge early in I 522 (see also the next letter). In the conveyance of the sermon from one person to another the last part was lost, and the Bishop had to rewrite it.

The 'Annotationes Erasmi' must be, I think, the New Testament of I 5 I6, which Erasmus had presented to his learned friend. 'You have made me your debtor in a vast amount of thanks by presenting me with the New Testament translated by you out of the Greek,' writes Fisher to Erasmus, June, I 5 I 6 (Erasmus' 'Letters,' Nichols, II. 293). Erasmus was in England later, and stayed for ten days in August of that year with Fisher at Rochester. Fisher's learning the Greek language was greatly stimulated by the visit of Erasmus, and we find Erasmus shortly afterwards writing to Reuchlin, from Antwerp, 2gth September: 'Colet . . . is now, at his age, learning Greek, in which the bishop of Rochester has also made good progress' ('Letters,' II. 396). Erasmus tried to get William Latimer to give the Bishop a month's teaching, his refusal to do so bringing a long and interesting letter of protest from Erasmus the following February ('Letters,' II. 509). The Bishop in a letter to Erasmus from Rochester, June, 1517 , criticises the New Testament, and 


\section{${ }^{1} 3^{8}$ LETTERS OF BISHOP FISHER.}

adds: 'I have you to thank, that I am able to some extent to guess where the Greek does not quite correspond with the Latin. I only wish I had been permitted to have you for a few months as a teacher' ('Letters,' II. 570).

Of Arnold the bookbinder, who is again mentioned in letter (5), I have failed to find any information. I cannot help thinking it is the same Arnold as the one mentioned in Erasmus' letter to Thomas Ruthall, Bishop of Durham, dated from Antwerp, gth July, $15^{16}$ :-

I heard . . . that the volume of Seneca had not then been delivered to you. Francis Birckman confesses that it was left with Arnold, from whom you will recover it, if you have not already received it ('Letters,' II. 305).

But the translator of Erasmus' letters says that this Arnold 'was probably Arnold Edward, see vol. i, 235.' This reference is to a letter from Erasmus to James Batt (a learned lawyer, Secretary or Town Clerk of Bergen-op-Zoom), dated from Paris, 12th April, I 500, and I should say is not to the Arnold of sixteen years later :-

My package ... had been entrusted, not to a sailor, but to Arnold Edward, a lawyer, who was to deliver it for transmission to the first suitable shipper he met with. His name is known to all London; and he lives in the house of his father, Master Edward, Merchant, on London Bridge. It does not matter whether you send to him or to Thomas More, who lives at Lincoln's Inn. I am surprised you do not know Arnold, as I sent you a letter of mine addressed to him, by the hands of that talkative messenger by whom I forwarded the Laurentius. I also gave him directions to make enquiry about that robber of 


\section{LETTERS OF BISHOP FISHER. 139}

ours, but he has neither sent any message back, nor have you written about it.

Wynkyn de Worde in his will (1 534) mentions one 'Alard,' his bookbinder, but this cannot be our man. My Lord's 'great labors agayns Luther' most probably refer to the writing of his 'Assertionis Lutheranae confutatio,' printed 1523, which he might have been writing at this time.

(3)

Addressed: To the ryght worshipfull $\mathbf{M}^{\mathbf{r}}$ Doctor Metcalf tharchdiaco of Rochest this lettre be dd.

Ryght worshipfull syr dew recomendacon p'missed. I am sory that I spak not $w^{t}$ yor $m^{r}$ ship at yor departyng. I was then sayng masse at the parish churche. I send to you by this berer now my lordes lettre which is to $\mathbf{M}^{r}$ Secretary I had it red \& therefore $y^{\circ}$ shall know somewhat of the tenor thereof. Fyrst there is thankes for his last lettres, then he signifyes to him the popes grete thankes for the sermon whiche thanks my lord rekenneth $M^{r}$ Secretary most wordy of all by cause he haith taken such paynes in to'nyng it in to latyn, thirdly he signifyeth to hym that one of the nonnes of Heigham wold be at Sainct Elyns desyryng his helpes therin. More ou syr $\mathrm{y}^{e}$ shall receyve of this berer my lordes sermon in ynglyshe which he $p^{r}$ yethe you to put to Wynkyn to prynt and he $p^{r} y e t h e$ you to speke to Jhon Gowghe to see it diligently done \& trewly printed. He signifyethe to. $\mathbf{M}^{r}$ Secretary that he puttes this to Wynkyn \& desyreth of hym one in latyn. I pry yow syr let one of yo seruandes delyuer to Maist Denton my lettre ther is one of $M^{s}$ Burbanke's $w^{t}$ in it. Christopher shall bryng to me your gown that it pleased yo" to geve me, if it so lyke you. No more but I beseche yo" remembre Thomas Bocher close if $\mathrm{my} \mathrm{labo}^{\mathrm{r}}$ be mayd for it \& $o^{x}$ Lord God kepe $y o^{x} m^{x}$ shipe from Sellyng this 10 Fryday

By yor Officiall. 


\section{LETTERS OF BISHOP FISHER.}

- My lordes lettre to $\mathbf{M}^{\prime}$ Secretary ... signifyes to him the popes grete thankes for the sermon . . . he haith taken such paynes in to'nyng it in to latyn.' Mr. Secretary is Richard Pace, who was appointed Secretary of State in 1516. The pope's thanks are for his Latin translation of the Sermon preached by bishop Fisher at St. Paul's, I 2th May, 1521, to which reference is previously made in letter. (2). Leo $X$ was pope when this sermon was preached, but died and December, I52I, and I cannot help thinking that the Latin version was sent to him in manuscript, and that, therefore, this letter was written before the end of 1521, for upon the death of Leo X, Pace was sent to Rome to advocate Cardinal Wolsey's candidature for the papacy, and he remained abroad for more than a year, certainly until 1 $4^{\text {th }}$ September, 1523, when Adrian VI died and Clement VII was elected. After a short rest at home he was sent to Venice, and was recalled in October, 1525. Certainly the Sermon in English had not been printed when this letter was written, and the same, I think, may be said of the Latin version, for that was printed at Cambridge by John Siberch early in 1522, with a long preface eulogistic of Richard Pace, by Nicholas Wilson, M.A., of Christ's College,' who dates his preface 'Kalend'. Ianuarii, M.D.xxI.,' and from this preface I should conclude that Wilson was responsible for its production. He therein speaks of the bishop as not having cared to make the translation.

'See Cooper's 'Ath. Cantab., I. 94, and the 'D.N.B.' 


\section{LETTERS OF BISHOP FISHER. I.4I.}

It is a curious question as to why Pace's Latin translation of the Sermon was not printed by Wynkyn de Worde, but by John'Siberch at Cambridge. It may have been by the interest of Nicholas Wilson, whose residence was at Cambridge, and who, as I have previously suggested, was responsible for its production, it being more easy for him to superintend the printing in his own town than to have it done so far away as London was in those days.

In his 'Century of the English Book-Trade' (p. I74), Mr. Gordon Duff says:-'About 1522 we find that De Worde was employing other presses.' Is it likely that Wynkyn de Worde employed Siberch to print this work for him?

Now in the letter to which these remarks are attached, the instructions are that Wynkyn de Worde was to print the Sermon in English (the manuscript accompanied the letter), and John Gough was to see it done, and also the Latin version (?). I think we have here absolute evidence of Gough's being servant, perhaps reader or foreman, to Wynkyn de Worde before he commenced business on his own account in 1528 , which might account for his being appointed an overseer of his old master's will. He is also mentioned in letter (2).

' One of the nonnes of Heigham.' This is Godlive (or Godliva) Lawrence, whose resignation at

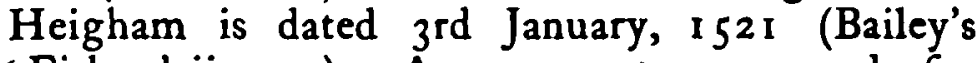
'Fisher,' ii, 311). Arrangements were made for her acceptance at St. Helen's Nunnery, within Bishopsgate, London, and the document of acceptance is dated 28 th January, $152 \frac{1}{2}, 64^{\circ}$ having 


\section{42 LETT ERS OF BISHOP FISHER.}

been paid (R. F. Scott in 'Eagle,' vol. xvii, No. 10 I).

This letter, I think, must be attached to the year I 521 .

Addressed: To the right worshipfull $\mathrm{M}^{\mathrm{r}}$ Doctor Metcafe Archdiacon of Rochester.

Humble recomendacions p'mysed. I have shewd to my lord the effect of yor letter the wych I receyvyd the last day of June. And wher as yor maistershipe desireth my lordes letters for the forderance of yor causes his lordshipe saithe he may not loose so moche tyme fro his other besines. And as towchyng yo statutes my lord will cause John Bottell to wrytt them. Mor ouer the ij articles de potestate pape \& de indulgencijs may not be sparyd for my lord hath the butt oons wryty $\bar{n}$ in $m \bar{u} d \bar{u}$ and also his lordship intendith to put them shortly to the pryntyng. Ther is no man $y_{t}$ will say my lord hath wrytyn frigide $8 x$ jeiune of thes ij articles that doth redd them $8 x$ vndyrstand them \& so my lord saith hymself whos jugment I belive wilbe takyn byfore theyres that say the contrary and not only $\mathrm{my}$ lord saith this but also diuers other well lernyd $\mathrm{y}^{\mathrm{t}}$ hath redd thes ij articles. I haue send to yor maistershipe the p'face of my lordes bok. I haue paid to Dame Peny's father vi' viij ${ }^{d}$ for hyr pesion. At the desire of $\mathrm{Mr}$ More my lord comawndyd me to pay to $\mathrm{Mr}$ Coltes doghtor \& her husband on Sonday last $\mathbf{v}$ markes for certain money \& stuff of hers that was left at $\mathrm{Hygh} \overline{\mathrm{m}}$. And thus our Lord God haue yor maistershipe in his graciose kepyng $\&$ likwise spede yow in yor besines, at Rochest the first day of Juli

$$
\begin{aligned}
& \text { yo bedmå } \\
& \text { Richard SHARpg }
\end{aligned}
$$

John Bottell is mentioned in a previous letter (2). 


\section{LETTERS OF BISHOP FISHER.}

The two articles 'de potestate papx' and 'de indulgenciis,' and also the 'preface,' no doubt refer to the writing of the "Assertionis Lutherana confutatio,' printed 1523, and mentioned in the previous letter (2).

Dame Peny or Penny was one of the nuns of the dissolved Higham nunnery which was granted to St. John's College, Cambridge. Her resignation is dated 2 Ist December, I 521 (Bailey's 'Fisher,' ii, $\left.\hat{3}^{1}\right)$. She was afterwards admitted to St. Sepulchre's Priory, Canterbury. The last prioress (Anchoreta Ungothorpe or Owglethorpe) died 3 Ist January, I 520.

Who Mr. Coltes' daughter and her husband were I cannot say. The other nuns at Higham at its dissolution, besides Eliz Peny, were Agnes Swayne and Godlif (or Godliva) Lawrence: see also letter (3).

Mr. More. Would this be a desire of Mr. More as 'Master of Requests,' also would this be the way of speaking of one who had been knighted in the Spring of 1521 ? The date of this letter appears to me Ist July, 1522.

\section{(s)}

Addressed: To the right wurshipfull Master Doctor Metcalfe Archdecon of Rochester.

My duty of comendacions premised Lyketh $\mathrm{yo}^{\mathrm{r}}$ mastership to take the Labor to delyur these to Bokes that is to saye Topica Claudii and Dialectica et rethorica Phi. Melanchton to John Rayns againe for my Lord hadde them of him before, and also desiring him to bynde this Booke called Direcioriü aure $\bar{u}$ contemplatiuorum in a parcheament ${ }_{10}$ skyn, for my lord. This Booke ye shall reseve of the 


\section{LETTERS OF BISHOP FISHER.}

Bearer hereof. My Lord hathe sertaine Bookes at binding at Arnoldis the wiche his Lordship woulde gladly haue if the be fynyshed Wherefor, if yor $\mathrm{m}^{\mathrm{r}} \mathrm{ship}$ maye haue any convenient messenger ye shall doo hyme great pleasor to send hyme these books. My Lord lyked the stourgen that ye sent him verey well and likewise fedde well of it. And he commanded it to be kept a weke or more. His Lordship wulbe at London shortly. But I know not the time. I haue many other thinges that I wuld haue written vnto (your?) m ship of butt 1 ame not able to hold the pen between my fyngers. as knowithe

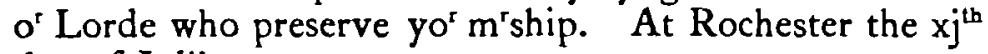
day of Julij

$$
\begin{aligned}
& \text { yor own to his lityll power } \\
& \text { RichaRD SHARPE }
\end{aligned}
$$

'Topica Claudii Cantiunculae' was printed by A. Cratander at Basle, 1520. P. Melancthon's 'Dialecta' was first published at Basle, 1520 , and again I 522, the 'rethorica' at Basle, 1519 . The work entitled 'Directorium aureum contemplativarium' I have not been able to identify.

Arnoldis (or Arnold) the bookbinder has already been mentioned as binding books for bishop Fisher: see letter (2).

This letter seems to imply that Reynes was in the habit of sending new and important books to the bishop on approval. In Duff's 'Century of the English Book-Trade' the first mention of him as a 'stacyoner' is in the Returns of Aliens for I 523, and I assign this letter to the I I th of July, I 522 or 1523 .

It is to be hoped that the good bishop further enjoyed the stourgeon after it had been kept a week or more (!) 


\section{LETTERS OF BISHOP FISHER. I 45}

I have to thank Mr. S. Gaselee and Mr. C. E. Sayle for information on some questions raised by these letters, and Mr. R. F. Scott for allowing me to reprint the letters which he will find here rearranged.

G. J. Gray. 